\title{
ON THE MANAGEMENT OF SINGLE FISH SPECIES OF HILSA SHAD (TENUALOSA ILISHA) RESOURCES OF BANGLADESH
}

\author{
M. Nath Sarker*, M. Niamul Naser ${ }^{1}$, Md. Sharif Uddin, N. Nanda Das ${ }^{2}$ \\ and Md. Humayun ${ }^{3}$ \\ Bangladesh Marine Fisheries Capacity Building Project, Department of Fisheries, \\ Matshya Bhaban, Dhaka, Bangladesh
}

\begin{abstract}
Hilsa shad (Tenualosa ilisha) belonging to the family Clupeidae is a diadromous migratory fish species. It is an important fish in the countries bordering to the Bay of Bengal. Bangladesh harvest about $60 \%$ of world hilsa catch. Hilsa contributed $12.9 \%$ of the country's total fish production in 2017-2018 with an estimated annual production of 517,198 tons, which was $1.0 \%$ to the GDP to support livelihoods of 1.2 million hilsa fishers of Bangladesh. In spite of the importance, there was an alarming situation in hilsa production, where over fishing of hilsa with a result of decline in inland production were observed. In the present study age and growth parameters $\mathrm{L}=57.7 \mathrm{~cm}$ total length and growth rate $\mathrm{K}=0.90$ per year were calculated using VBGF growth function. Population parameters $Z=4.90$ were calculated using length converted catch curve, M (at water temperature $27^{\circ} \mathrm{C}$ ) $=1.45$ using Pauly's formula, $\mathrm{F}=1.09$ and $\mathrm{E}=70$ were estimated. Results indicates both recruitment overfishing and growth over fishing occur through indiscriminate fishing of juvenile hilsa (Jatka) as wel as brood hilsa(mother). Fishing effort has to be reduced at any cost and the affected fishers should be rehabilitated in a proper manner for obtaining the sustainable production of hilsa resources.
\end{abstract}

Key words: Management, hilsa shad, Tenualosa ilisha

\section{INTRODUCTION}

Hilsa fish (Tenualosa ilisha) is famous for its unique taste and flavor among the Bengali communities throughout the world. Diadromous hilsa fish is the national fish of Bangladesh and seems to be a most important aquatic resource comprising the single largest fishery in Bangladesh. Hilsa fish production in the year 2017-2018 was 517, 198 tons(FRSS 2018) with landed value more than2500 million USD. The hilsa fishery contributes about $1 \%$ to the total fisheries sector GDP in Bangladesh (Ahsan et al. 2014); About12.9\% of the country's total fish production is generated by this fishery (FRSS 2018).

*Author for correspondence: <mn_sarker2001@yahoo.com>. 1Department of Zoology, Faculty of Biological Sciences, University of Dhaka, Dhaka 1000, Bangladesh. ${ }^{2}$ HFLIP, LGED, Dhaka, Bangladesh. ${ }^{3}$ Center for Development Initiatives in Capture Fisheries (CDICF)

(c) 2018 Zoological Society of Bangladesh DOI: https://doi.org/10.3329/bjz.v47i1.42055 
The most part of the hilsa fishery is conducted by small scale low technology artisanal fishermen numbering in excess of four lakh twenty thousand (Halder 1998).This fishery provides livelihood directly or indirectly to about 2.5 million people( $2 \%$ of the total population).The reduction in the depth and discharge of riversdue to construction of dams and barrages has affected the spawning, feeding and migration of this fish (Ahsan et al. 2014, Naser et al. 2019).

Hilsa belongs to the Family Clupeidae and occurs in marine, estuarine and river environments. Particularly large stocks are found in upper Bay of Bengal region sustained by the large river systems like Meghna. Historically until 1972, the upstream rivers were characterized by high abundance of hilsa. Subsequently, abundance in the upstream rivers started declining gradually, though simultaneously it increased in the downstream, the estuaries and the sea (Naser et al. 2019). However, total production has remained stable at present due to an increased harvest at the marine sector.

In Bangladesh hilsa may reach up to $60 \mathrm{~cm}$ in total length and $3 \mathrm{~kg}$. in weight at four years of age (Sarker et al. 2016). Most commonly found hilsa is 35 to $40 \mathrm{~cm}$ in length and less than one $\mathrm{kg}$ in weight. Mature hilsa migrate upstream primarily during the southwest monsoon and consequent flooding of the rivers (Rahman 2000, Ahsan et al. 2014). The larvae and juveniles make their way downstream to the sea during a period of 5-6 months feeding and growing on the way. At an age of about six to ten weeks the fry have grown to about $12-20 \mathrm{~cm}$. $(0.1 \mathrm{~kg}$ in weight). At this size they are known as "jatka" and subject to heavy fishing mortality. Maturity occurs between 6 and 12 months of age where the survivors undertake their first spawning migration upriver (Rahman 1998, Naser 2018).

Hilsa fishery seems to be very remunerative in comparison with other profession but it is not true as the fishing effort is risky and depends upon seasonal availability. The current problem is very detrimental as there is limited control of over fishing in artisanal fishery in Bangladesh. This could be harmful for future of the hilsa fishery as seen on other major fisheries in the world by (Beddington et al. 2007). Among the 13 techniques practiced for the management of single species of the world (Melnychuk et al. 2016), only a few are implemented in Bangladesh. The demand of hilsa is high and there is no legislative limitation for fishing throughout the country. Hilsa fishing appears to be a very easy means of lively-hood in the riverine people of Bangladesh. This study will assess the present data to interpret the impact of present management tools for a single fisheries species of Bangladesh viz. hilsa. 


\section{MATERIAL AND METHODS}

Data from the Land Based Survey under Bangladesh Marine Fisheries Capacity Building Project, DoF has been used for the present study. Bangladesh Marine Fisheries Capacity Building Project has been conducting Land Based Survey for Population Dynamics and Stock Assessment of Marine Fishes of Bangladesh from September 2012 up to August, 2018. Altogether 32 fish landing stations have been selected for data collection from 14 coastal districts of Bangladesh. Weekly sampling on landing, length-frequency, gonad maturity data were collected in 4 different formats. Datathus collected has been entered in the database. From the data base required information were used for processing with FiSAT program. The hilsa fishery is described by the available data from the Riverine Station, Bangladesh Fisheries Research Institute, and FRSS, Department of Fisheries.

Length-frequency data of Tenualosa ilisha were collected weekly from the commercial catches from 35 different landing centers of Bangladesh coastal districts from September, 2013 to August, 2016. Samples of Tenualosa ilisha were mainly caught by seine net and gill nets. Random samples of 8500 specimens were collected. The length-frequency data were pooled month-wise.

Study area: The study area of this research work covering the entire coastal area starting from Teknaf, Cox's Bazar up to Shyamnagar, Satkhira. Data collected from 35 selected marine fish landing stations under 49 upazilla of 14 districts along the coastal belt of the Bay of Bengal.

Data processing and analysis: Estimation of Asymptotic length $\left(\mathrm{L}_{\infty}\right)$ and Growth co-efficient (K): Month-wise length-frequency data were used to estimate the total asymptotic length $\left(\mathrm{L}_{\infty} \mathrm{cm}\right)$ and growth co-efficient (K year-1) of the Von Bertalanffy growth equation (Bertalanffy 1938, Beverton and Holt 1957). The data collection period started from September and were continued up to August 2013. The ELEFAN I and ELEFAN II routines incorporated in FiSAT II (FAO ICLARM Stock Assessment Tools) Software (Gayanilo, Per Sparre and Pauly, 2005) were used to determine $\mathrm{L}_{\infty}$ and $\mathrm{K}$ values following the PowellWetherall method (Wetherall et al. 1987). This method was used to provide an initial estimate of $L_{\infty}$. This initial estimate of $L_{\infty}$ was then used as seed value to determine the value of K (Silvestre and Graces, 2004). Minor adjustments to $\mathrm{L}_{\infty}$ and $\mathrm{K}$ were made to maximize the 'goodness of fit' criterion built in to ELEFANI (Pauly 1987). This led to a preliminary estimate of $\mathrm{L}_{\infty}$ and $\mathrm{K}$ that were used to obtain "probability of capture" by length class using the routine in FiSAT. These "probability of capture" were used to correct the length- frequency distribution data to account for incomplete selection and recruitment and the final estimate 
of $\mathrm{L}_{\infty}$ and $\mathrm{K}$ were obtained by using the corrected length-frequency data through ELEFAN I (Silvestre and Graces 2004).

Estimation of mortality: In FiSAT II software package (Gayanilo and Pauly 1997), ELEFAN II was used to estimate the total mortality $Z$ (year-1) using the Length Converted Catch Curve by means of final estimates $\mathrm{L}$ and $\mathrm{K}$ and length-frequency data (Beverton and Holt, 1957, 1966) for the species T.ilisha. The rate of natural mortality $\mathrm{M}$ (year-1) for the species was calculated by using Pauly's empirical equation (Pauly, 1983):

$\operatorname{Ln} \mathrm{M}=-0.0152-0.279 \operatorname{Ln}\left[\mathrm{L}_{\infty}\right]+0.6543 \operatorname{Ln}[\mathrm{K}]+0.463 \operatorname{Ln}[\mathrm{T}]$

This formula was used to obtain the estimate of $M$, given $L_{\infty}$ in $\mathrm{cm}, K$ the growth constant and $\mathrm{T}$ the mean environmental temperature ${ }^{\circ} \mathrm{C}$. Once $\mathrm{Z}$ and $\mathrm{M}$ were obtained, then fishing mortality $\mathrm{F}$ was derived from the relationship $\mathrm{F}=\mathrm{Z}$ M (Silvestre and Graces 2004 ). The exploitation rate $\mathrm{E}$ was obtained by the relationship: $\mathrm{E}=\mathrm{F} / \mathrm{Z}=\mathrm{F} /(\mathrm{F}+\mathrm{M})$ (Beverton and Holt, 1956).

Probability of capture: Probability of capture calculated from the length converted catch curve routine and estimated the final $\mathrm{L}_{25}, \mathrm{~L}_{50}$ and $\mathrm{L}_{75}$ (Length at which $25 \%, 50 \%$ and $75 \%$ of fish would be vulnerable to the gear (Pauly, 1984).

Recruitment pattern: Recruitment Pattern was obtained by the backward projection of the frequencies on the time axis of a time series of samples along a trajectory defined by the Von Bertalanffy growth equation (Moreau and Cuende, 1991). This routine reconstructs the recruitment pulses from time series of length-frequency data to determine the number of pulses per year and the relative strength of each pulse (Gayanilo et al. 2005).

Relative yield-per-recruit and relative biomass-per-recruit: The Relative Yieldper-Recruit $\left(\mathrm{Y}^{\prime} / \mathrm{R}\right)$ was computed using the following formula (Gayanilo and Pauly 1997, Beverton and Holt 1966 ):

$$
\mathrm{Y}^{\prime} / \mathrm{R}=\mathrm{E} . \mathrm{U} \mathrm{m}\left\{1-\frac{3 U}{(1+m)}+\frac{3 U^{2}}{[(1+2 m)}-\frac{U^{3}}{-(1+3 m)}\right\}
$$

where, $U=1-(\mathrm{Lc} / \mathrm{L} \infty), \mathrm{m}=(1-\mathrm{E}) /(\mathrm{M} / \mathrm{K})=\mathrm{K} / \mathrm{Z}, \mathrm{Lc}=$ length of fish at first capture i.e. length at which $50 \%$ of the fish are retained by the gear and $\mathrm{E}=\mathrm{F} / \mathrm{Z}$. Relative Biomass-per-Recruit $B^{\prime} / R$ was estimated from the relationship $B^{\prime} / R=$ $\left(\mathrm{Y}^{\prime} / \mathrm{R}\right) / \mathrm{F}$

The value of Emax, EO.1 and EO.5 were estimated by using the first derivative of this function, where, Emax= maximum sustainable exploitation rate, $E 0.1=$ exploitation rate at which the marginal increase of relative yield-perrecruit is $1 / 10$ th and $E 0.5=$ value of $\mathrm{E}$ under which the stock has been reduced to $50 \%$ of its unexploited biomass. 


\section{RESULTS AND DISCUSSION}

In the present study age and growth parameters $\mathrm{L}=57.7 \mathrm{~cm}$ total length and growth rate $\mathrm{K}=0.90$ per year (Fig. 1) were calculated using VBGF growth function. Population parameters $Z=4.90$ were calculated using length converted catch curve, $\mathrm{M}\left(\right.$ at water temperature $\left.27^{\circ} \mathrm{C}\right)=1.45$ using Pauly's formula, $\mathrm{F}=1.09$ and $\mathrm{E}=70$ were estimated (Figs. 2 and 3 ).

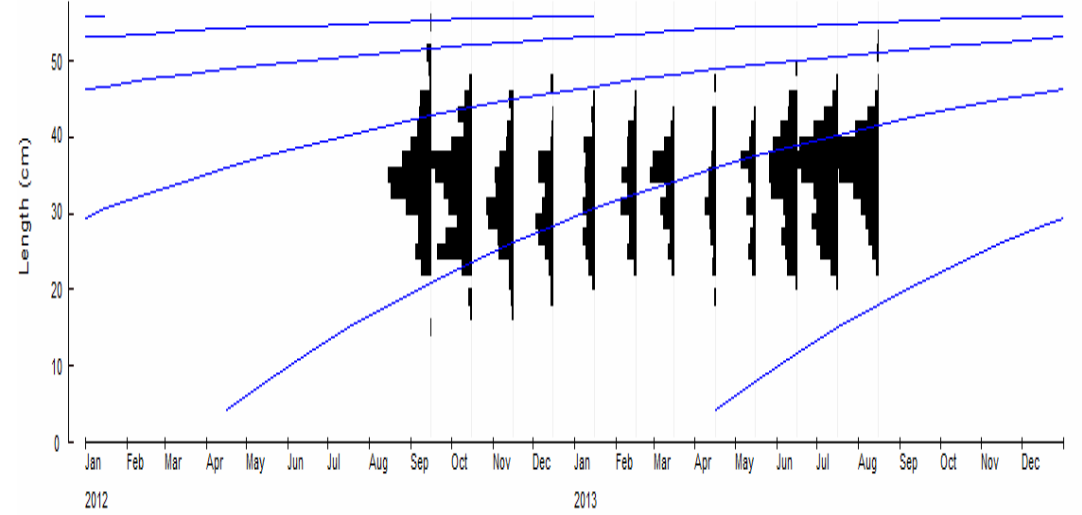

Fig. 1. Growth curve of T.ilisha from Bangladesh by ELEFAN-1 superimposed on the restructured length-frequency of Tenualosa ilisha $L_{\infty}=57.7 \mathrm{~cm}$ TL and $K=0.90 \mathrm{yr}^{-1}$ ).

\section{Length-Converted Catch Curve}

(for $Z=4.90 ; M\left(\right.$ at $\left.27.0^{\circ} \mathrm{C}\right)=1.45 ; F=3.45 ; E=0.70$ )

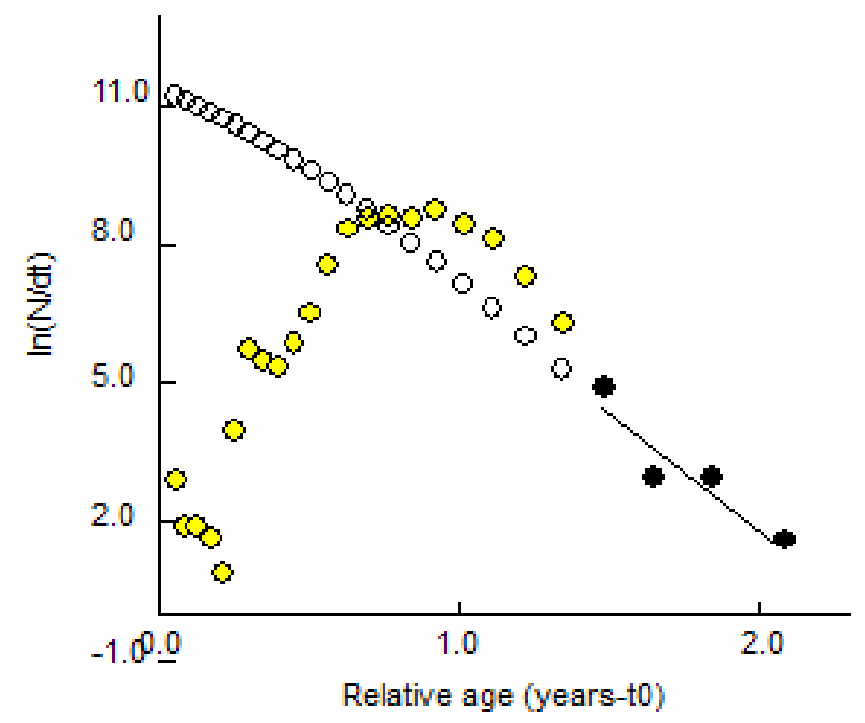

Fig.2. Length converted catch curve of Tenualosa ilisha 


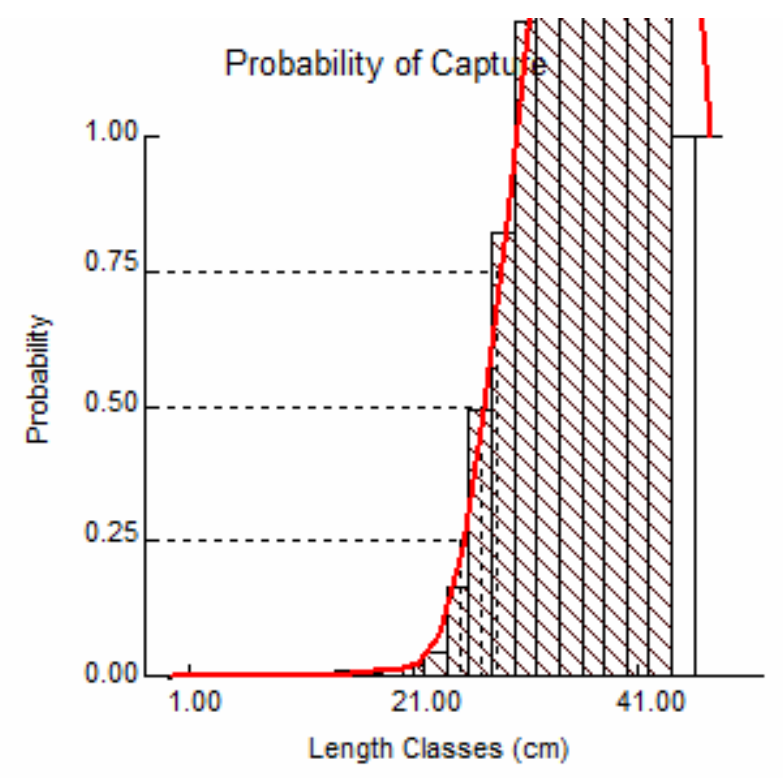

Fig.3. Probability of capture of Tenualosa ilisha.

Dutta et al (2012) described the population parameter of hilsa as $\mathrm{L}_{\infty}=$ $47.75, \mathrm{~K}=1.900$ per year, $\mathrm{Z}=1.98, \mathrm{M}=1.25, \mathrm{~F}=0.73, \mathrm{E}=0.37$ from the West Bengal coast, India.(Nurul Amin et al. 2002) mentioned $\mathrm{L}_{\infty}=60.00 \mathrm{~cm}, \mathrm{~K}=0.82$ per year, $Z=3.77, \mathrm{M}=1.28, \mathrm{~F}=2.49, \mathrm{E}=0.66$ in Bangladesh waters. Panhwar and Liu (2012), found $\mathrm{L}_{\infty}=31.5 \mathrm{~cm}, \mathrm{~K}=1.5$ year $^{-1}, Z=2.89, \mathrm{M}=2.21, \mathrm{~F}=$ $0.673, \mathrm{E}=0.35$, in Sindh coast. Roomani and Jamili (2011) found Lo $=42.74$ $\mathrm{cm}, \mathrm{K}=0.77$ per year, $\mathrm{Z}=2.55 \mathrm{yr}, \mathrm{M}=0.75, \mathrm{~F}=1.8$, in Iranian waters. Reuben et al. (1992), found $\mathrm{L}_{\infty}=595 \mathrm{~mm}, \mathrm{~K}=0.481 /$ year, $Z=1.75, \mathrm{M}=0.74, \mathrm{~F}=1.01$, $\mathrm{E}=0.5883$, to $=-0.0889$ in North East coast in India. Halder (2008). described $\mathrm{L}_{\infty}=53.60 \mathrm{~cm}, \mathrm{~K}=0.60 /$ year, $Z=3.03, \mathrm{M}=1.09, \mathrm{~F}=1.94, \mathrm{E}=0.64, \mathrm{Emax}=$ $0.63, \mathrm{Lc}=21.21, \varnothing=3.03$ in Meghna river of Bangladesh.

In the present study $\mathrm{L}_{\infty}=57.7 \mathrm{~cm}, \mathrm{~K}=0.80 /$ year, $\mathrm{Z}=4.90, \mathrm{M}=1.45, \mathrm{~F}=$ $3.45, \mathrm{E}=0.70$ were obtained. (Sarker et al 2016). The results indicate the alarming situation with clear indication of over fishing of hilsa. Both recruitment over fishing and growth over fishing were observed as indiscriminate fishing of juvenile hlisa (Jatka) and brood hilsa was going on. The Department of Fisheries, Bangladesh Fisheries Research Institute, Riverine Station, Chandpur took initiative to find out the real situation. Study conducted and according to the result obtained precautionary measures were taken by the Govt., and thus the stock of hilsa revived with increase in production in all environments. A set of criteria were fixed for the conservation of the hilsa resources. A seasonal ban 
of juvenile hlisa (Jatka) was introduced throughout the country from November to June. Size of Jatka were fixed to 25 centimeters and the use of monofilament net known as "Current Jal" were declared ban, which was indiscriminately used for easy harvesting of Jatka by the fishermen. This was possible due to proper application of "Payment for Ecosystem Services (PES)", that means subsidy and "Alternate Income Generating Activities (AIGA)" for the fishers during the ban period for hlisa conservation. Seasonal ban (November-June) on jatka fishing started from 2003 and periodical ban on brood hlisa fishing (SeptemberOctober-depending on full moon of Laxmi Puja) started from 2007. More over hlisa sanctuary were declared in the specific area with fishing ban during March-April period from 2007 (Table 1), and strong monitoring control and surveillance MCS system were applied throughout the country which makes the conservation of Hilsa program a success.

Table 1. Different types of conservation measures taken for Hilsa fish protection by DoF

\begin{tabular}{|c|c|c|c|}
\hline $\mathrm{S} 1$ & Activities & Time frame & Mode of action \\
\hline 1. & $\begin{array}{l}\text { Seasonal ban of juvenile } \\
\text { hilsa (Jatka) catch }\end{array}$ & $\begin{array}{l}\text { November to } \\
\text { June }\end{array}$ & $\begin{array}{l}\text { Food assistances were given to fisher's family } \\
\text { at the rate of } 40 \mathrm{~kg} / \text { family under Vulnerable } \\
\text { Group Feeding (VGF) program }\end{array}$ \\
\hline 2. & $\begin{array}{l}\text { Seasonal ban on fishing } \\
\text { mother (Gravid) hilsa }\end{array}$ & $\begin{array}{l}\text { October } \\
\text { (around full } \\
\text { moon period } \\
\text { of Laxmi puja) }\end{array}$ & $\begin{array}{l}\text { Assistance in the form of AIGA, including small } \\
\text { trade, cow/goat fattening, poultry rearing, } \\
\text { rickshaw/van, sewing machine, fishing net and } \\
\text { cage culture activities were created among } \\
\text { affected fisher's family. }\end{array}$ \\
\hline 3. & $\begin{array}{l}\text { Ban on use of } \\
\text { monofilament net } \\
\text { "Current Net" }\end{array}$ & $\begin{array}{l}\text { Round the } \\
\text { year }\end{array}$ & $\begin{array}{l}\text { Awareness building and mobile court operation } \\
\text { in major hilsa catching area }\end{array}$ \\
\hline 4. & $\begin{array}{l}\text { Combined operation for } \\
\text { eradicating the } \\
\text { destructive fishing gear } \\
\text { operation }\end{array}$ & $\begin{array}{l}\text { Special } \\
\text { program }\end{array}$ & $\begin{array}{l}\text { Combined operation for eradicating the } \\
\text { destructive fishing gear operating through } \\
\text { forming special team in the concerned area }\end{array}$ \\
\hline 5. & $\begin{array}{l}\text { Observation of } \\
\text { Jatka(juvenile hilsa) } \\
\text { conservation week }\end{array}$ & March & $\begin{array}{l}\text { To create awareness for protection and } \\
\text { conservation of Jatka }\end{array}$ \\
\hline 6. & $\begin{array}{l}\text { Observation of National } \\
\text { Fish Week }\end{array}$ & July/August & $\begin{array}{l}\text { To create awareness for protection and } \\
\text { conservation of fish including Hilsa }\end{array}$ \\
\hline 7. & $\begin{array}{l}\text { Ban on hilsa fishing in } 6 \\
\text { Hilsa sanctuary }\end{array}$ & March- April & $\begin{array}{l}\text { Five sanctuary of Hilsa were established in the } \\
\text { potential hilsa area with seasonal ban of all } \\
\text { type of fishing }\end{array}$ \\
\hline 8. & $\begin{array}{l}\text { Special operation for } \\
\text { Hilsa conservation act } \\
1985 \text { by operating } \\
\text { mobile court in the } \\
\text { riverine area }\end{array}$ & $\begin{array}{l}\text { As and when } \\
\text { necessary } \\
\text { round the year }\end{array}$ & $\begin{array}{l}\text { Operation of mobile court with the help of } \\
\text { Judicial Magistrate and law enforcing agency } \\
\text { throughout the reverie area }\end{array}$ \\
\hline
\end{tabular}

Due to the depletion of fish in upstream areas, hilsa fishing has moved to downstream and especially to inshore marine waters where sufficient 
concentrations of hilsa are now found. In these areas hilsa fishing requires more fishing capital and is more expensive. Adequate limitations, controls on fishing vessels and fishing effort have not been in place to counter the expansion in this sector of the fishery (Halder 2004). In addition to overexploitation of the hilsa stocks, fishing vessel crowding on the best fishing grounds has been a problem. In spite of its economic importance, it is not found any systematic studies of the economics of the hilsa fishery. To maintain and enhance the hilsa stock, many biologically-based management measures have been introduced.

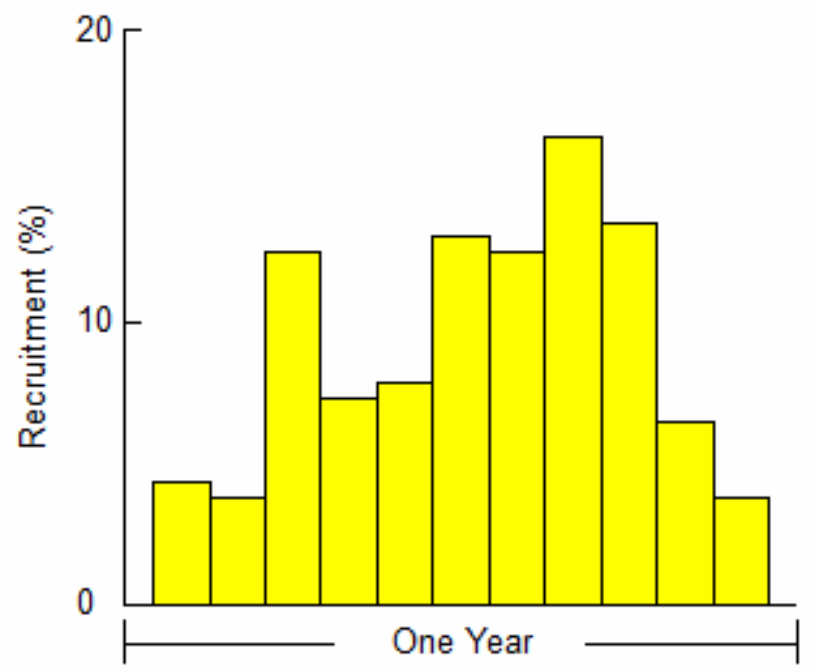

Fig. 4. Recruited pattern of Tenualosa ilisha on the basis of data of one year starting from September, 2012 to August, 2013.

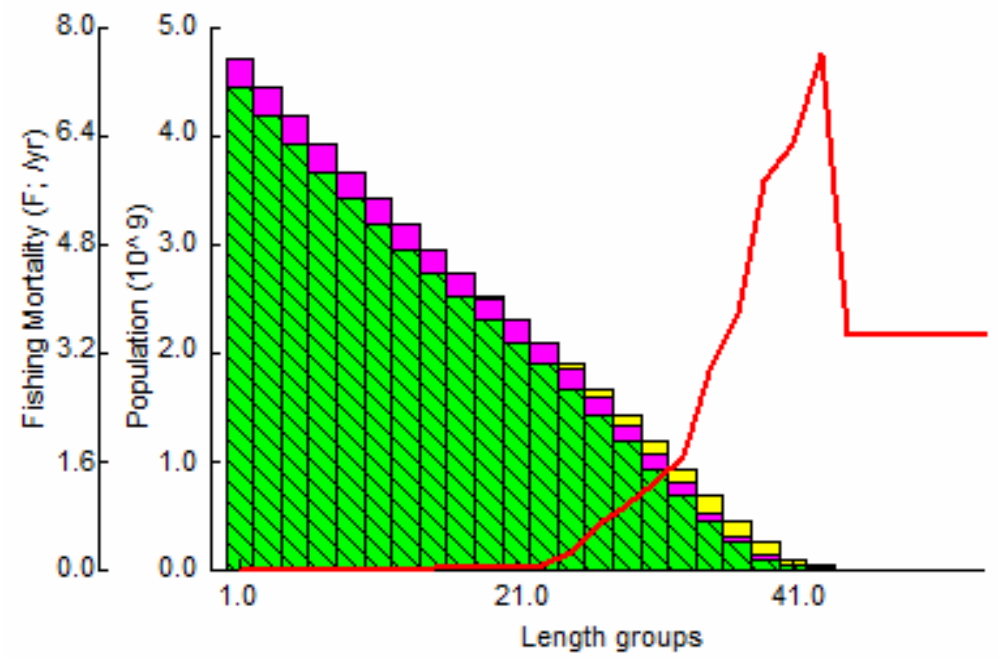

Fig. 5.Length-structured virtual population analysis of Tenualosa ilisha. 


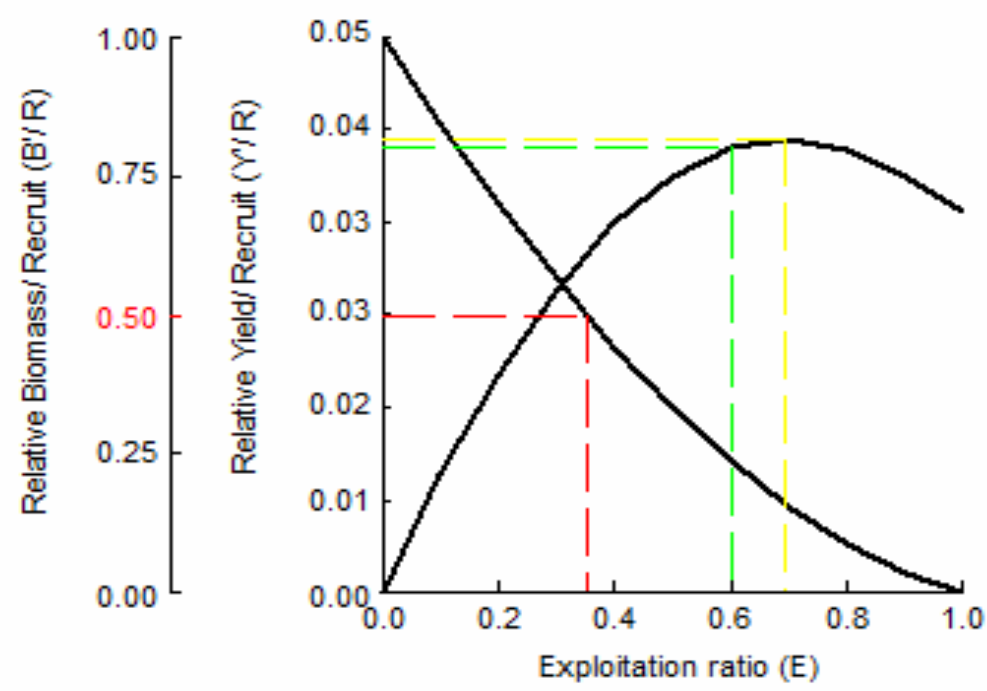

Fig. 6. Relative yield/recruit and biomass/recruit of Tenualosa ilisha

There is direct relationship of hilsa landing with total rain fall of the spawning areas (Das et al. 1992). Annual variation in hilsa landing showed a significant negative correlation with local rainfall 2 years previously. This is true for both in the Ganges river in Bangladesh and in Indus river Pakistan(Das et al. 1992). The mechanism relating the negative association between landings and rainfall 2 years earlier may be that heavy rainfall may wash away eggs and larvae, and that hilsa are $1+$ years old when they are recruited to the fisheries. Annual landing some times vary in opposite direction in Ganges and Indus River. In each region annual landings are dependent in part on rainfall two years earlier in that region. This dependency offers a means of rough forecast of annual harvest on the basis of annual rainfall data.

\section{CONCLUSION}

It is obvious that, growth and recruitment over fishing happened; on the other hand fishing efforts has an increasing trend. Initiatives for proper management so far taken, seems to be not enough for a sustainable production of Hilsa fish. This is due to huge number of fishers with numerous fishing boats and nets engaged in Hilsa fishing. Hence it could be concluded that, for the sustainable production of hilsa, fishing effort have to be reduced in addition to all the measures taken by the concerned authority. The Payment for Ecosystem Services system should be enhanced throughout the entire coastal fishing area, so that fishers do not suffer during ban period for jatka and gravid hilsa

protection. MCS system should be strengthened. "Hilsa Development Trust 
Fund" has to be used carefully, which is initiated with a view to help poor and helpless poor in light of the model created for the beneficiaries. The "One House One Farm" and Polly Sanchay Bank could play a vital role for the conservation of Hilsa, providing soft loan to the fishers. Hilsa fishing effort should be reduced to a substantial number. As hilsa fishery is a common or shared stock with other maritime countries like India and Myanmer bordering the Bay of Bengal, action plan regarding Hilsa management should be organized and implemented in a same way through coordinated effort. National forecasting system for Hilsa availability should be developed. Only registered and conscious fishers should be allowed to catch Hilsa with legal and appropriate crafts and gears in a particular area, with local quota for system for harvesting have to be developed.

\section{LITERATURE CITED}

AHSAN, D.A., NASER, M.N., BHAUMIK, U., HAZRA, S. and BHATTACHARYA, S.B. 2014. Migration, spawning patterns and conservation of Hilsa shad (Tenualosa ilisha) in Bangladesh and India. Academic Foundation. New Delhi, India, 95p.

BEDDINGTON, J.R., AGNEW, D.J. and CLARK, C.W. 2007. Current Problems in the Management of Marine Fisheries. Science. 316, 1713- 1716.

BERTALANFFY, L.V. 1938. A Guantitative Theory of Organic Growth. Human Biology 10:181-213 p.

BEVERTON, R.J. and HOLT, S.J. 1957. On the dynamics of exploited fish pupations. Fish. Invest.London.Series 2, 19: 553.

BEVERTON, R.J.H. and HOLT, S.J. 1956. A review of methods for estimating mortality rates infish populations with special references to sources of bias in catch sampling. Rapp. P-V. Renn. Cons.Int.Explor.Mer. 140: 67-83 p.

BEVERTON, R.J.H and HOLT, S.J. 1966.Manual of Methods for Fish Stock Assessment, Part 2.In:Tables of Yield Functions, Fisheries Technical Paper No. 38. Food and Agriculture Organization of the United Nations, Rome, Italy, 7-29 pp.

DAS, N.N, LINDSEY C. C. and KHAN, M.S. 1992. Correlations between annual catches of the Hilsa shad Tenualosailisha in the Ganges and Indus River and rainfall two year earlier. (Ed. Chou L.M., Munro, A.D, Lam, T.J, Chen, T.W. Chong, L.K.K, Ding, J.K, Hooi, K.K., Khoo, H.W., Phang, V.P.E, Shim, K.F. and Tan, D.H.) 1994. Proc. The Third Asian Fisheries Forum. Asian Fisheries Society, Manila, Philippines. 228-231 pp.

DUTTA, S,S.Maity, A.Chanda and S Hazra.2012. Population structure and exploitation rate of Hilsa shad (Tenualosa ilisha) in West Bengal Coast of Nortyhern Bay of Bengal, India. World Journal of Fish and Marine Science.4(1):54-59 pp

FRSS.2018. Yearbook of Fisheries Statistics of Bangladesh. Fisheries Resources Survey System,(FRSS), Department of Fisheries Bangladesh. 35:121.

GAYANILO, F.C. and PAULY, D. 1997. The FAO ICLARM Stock Assessment Tools (FiSAT) : Reference Manual. Food and Agriculture Organization of the United Nations, Rome, Italy.15-42 pp.

GAYANILO, F.C., SPARRE, P. and PAULY, D. 2005. FAO-ICLARM Stock Assessment Tools II (FiSATII), User's Guide, Computerized Information Series (Fisheries) No. 8, (Revised Version),Food and Agriculture Organization of the United Nations, Rome, Italy. 459 p.

GULLAND. J.A. 1971. The Fish Resources of the Oceans, Fishing News, London. 9-52 pp. 
HALDAR, G. C. AND RAHMAN, M. A.1998. Ecology of Hilsa, Tenualosa ilisha (Hamilton). In: Proceedings of BFRI/ACIAR/CSIRO Workshop on Hilsa Fisheries Research in Bangladesh, held on 3-4 March 1998 at Bangladesh Agricultural Research Council, Dhaka, Bangladesh. (Ed. M.A. Mazid and S.J.M. Blaber.). BFRI 6: 86.

HALDER, G.C. 2004. Present status of the Hilsa fisheries in Bangladesh: Report on hilsa management and conservation studies conducted under the ARDMCS, GEF Component, FFP, DoF. 70 p.

MELNYCHUK, M.C., PETERSON, E., ELLIOTT, M. and HILBORN, R. 2017. FISHERIES MANAGEMENT IMPACTS ON TARGET SPECIES STATUS. PNAS 114(1): 178-183.

MOREAU, J. and CUENDE, F. X.1991.On improving the resolution of the recruitment patterns of fishes. Fish byte $\mathbf{9}(1)$ : 45-46

NASER, M.N. 2018. Hilsa Shad (Tenualosa ilisha)-the iconic fish of the Bengal Delta. In: Nishat B, Mandal S, Pangare G, editors. Conserving Ilish, Securing livelihoods: Bangladesh-India initiatives. India: IWA, Academic Foundation. New Delhi, India. 37-52 p.

NASER, M.N., BADHON, M.K. and CHOWDHURY, M.S.M. 2019. Towards Improving the Migration Route Connectivities of Hilsa Shad (Tenualosailisha) at the Meghna Estuary of Bangladesh. M.E.Islam, edt. Environmental Thoughts, Part 1, Centre for Management Research and Information Technology, Dhaka 1000, Bangladesh. 7-16 pp.

NURUL AMIN, S.M. RAHMAN,M.A., HALDAR,G.C., MAZID, M.A. and MILTON, D. 2002. Population Dynamics and Stock Assessment of Hilsa Shad, Tenualosailishain Bangladesh. Asian Fisheries Science. 15: 123-128.

PANHWAR, S.K. and LIU, Q. 2012. Population statistics of the migratory hilsa shad,Tenualosailisha, in Sindh, Pakistan. Journal of Applied Ichthyology. 29(5): 1091-1096. Doi: $10.1111 /$ jai. 12134

PAULY, D. 1987. Review of the ELEFAN System for analysis of length-frequency data in fish and aquatic invertebrates. In: Pauly, D. and Morgan, G.R. eds., Length-Based Methods in Fisheries Research, Conference Proceedings, International Center for Living Aquatic Resource Management, Manila, Philippines. 5-8 pp.

RAHMAN, M.A., AMIN, S.M.N., HALDAR, G.C. and MAZID, M.A. 2000. Population dynamics of Tenualosailisha of Bangladesh waters. Pakistan Journal of Biological Science 3: 564-567.

RAHMAN, M.A., NURUL AMIN, S. M., and HALDER, G. C. 1999. Some aspects of population dynamics of adult Tenualosailisha from Barisal coastal region of Bangladesh. Journal of Asiatic Society 25:225-233.

ROOMANI, L., and S. JAMILI. 2011.Population Dynamics and Stock assessment of Hilsa Shad Tenualosailisha in Iran (Khuzestan Province) Journal of Fisheries and Aquatic Science 6(2): 151-160.

SARKER, M.N., RAHMAN, M.J., ISLAM, ABM.A. and RAHMAN, A. 2016. Population Dynamics of Marine Fishes of Bangladesh. In Consultative workshop on the result obtained from the land based survey. Report-1. Bangladesh Marine Fisheries Capacity Building Project, DoF. 15 p.

SILVESTRE, G.T. and GARCES, L.R. 2004. Population parameters and exploitation rate of demersal fishes in Brunei Darussalam. Fish Research, 69: 73-90.

WETHERAll. A., POLOVINA, J.J. and RALSTON, S. 1987. Estimating Growth and Mortality in Steady-State Fish Stocks from Length-Frequency Data. In: Pauly, D. and Morgan, G.R.(Eds.).Length-Based Methods in Fisheries Research, Conference Proceedings, International Center for Living Aquatic Resource Management, Manila, Philippines. 1-22 pp. 